\title{
O DECLÍNIO DO ESTADO NOVO, A LEGISLAÇÃO ELEITORAL E A ATUAÇÃO DE OTÁVIO MANGABEIRA NA CAMPANHA DA UDN BAIANA - 1945
}

\author{
THE DECLINE OF ESTADO NOVO, THE ELECTION LEGISLATION \\ AND THE ACTION OF OTÁVIO MANGABEIRA IN UDN'S \\ CAMPAIGN OF BAHIA - 1945
}

DOI: http//dx.doi.org/10.15448/2178-3748.2017.2.27430

\author{
Eliana Evangelista Batista \\ Doutoranda em História - UFBA \\ eliana25d@hotmail.com
}

\begin{abstract}
RESUMO: Pretende-se discutir neste artigo de que modo as regulamentações impostas às primeiras eleições que marcaram o declínio do Estado Novo, pelo Ato de ${ }^{\circ} 9$ e pelo Decreto-Lei no ${ }^{\circ} .856$, ambos de 1945, impactaram na organização dos partidos políticos na Bahia, especialmente sobre a UDN, desdobramento da Concentração Autonomista, agremiação política que fez oposição a Vargas desde as eleições de 1934. Investiga-se, também, a relação desse Partido com os eleitores baianos, verificando as estratégias dos dirigentes políticos para lidaram com as novas determinações da legislação eleitoral, no intuito de fortalecer a agremiação partidária e agregar votos de uma parcela significativa de eleitores que, pela primeira vez, iriam participar do pleito eleitoral. Nesse processo, destaca-se o papel exercido por Otávio Mangabeira que desde 1930, quando foi deposto do cargo de Ministro das Relações Exteriores do governo de Washington Luís, passou a atuar contra o governo Vargas, seja no exílio, onde esteve a maior parte do período varguista ou no Brasil durante o governo constitucional, entre os anos de 1934 e 1937.
\end{abstract}

PALAVRAS-CHAVE: Estado Novo. União Democrática Nacional. Otávio Mangabeira.

\begin{abstract}
It is intended to discuss in this article how the regulations imposed on the first elections that marked the decline of Estado Novo, Act no. 9 and Decree-Law no. 7.856, both from 1945, impacted on the organization of political parties in Bahia, especially on the UDN, an unfolding of the Concentração Autonomista, a political organization that opposed Vargas since the 1934 elections. It is also investigated the relation of this Party with the voters of Bahia, verifying the strategies of the political leaders to deal with the new determinations of the electoral legislation, in order to strengthen the party association and add votes of a significant number of voters who, for the first time, would participate in the election lawsuit. In this process, the role played by Otávio Mangabeira, who since 1930, when he was dismissed from his position as Minister for Foreign Affairs, from the government of Washington Luís took a stand against the Vargas, in exile, where he spent more most of the Vargas period or in Brazil during the constitutional government, between the years of 1934 and 1937.
\end{abstract}

KEYWORDS: Estado Novo. União Democrática Nacional. Otávio Mangabeira.

\section{Considerações Iniciais}

Durante o declínio do Estado Novo, no ano de 1945, uma das últimas tarefas e preocupações do governo Vargas foi a de elaborar o sistema que regeria os futuros processos eleitorais. Essas leis, além de determinarem a organização partidária e a realização das eleições, apresentaram consequências políticas mais profundas, pois definiram questões relativas aos 
registros de partidos, bem como definiram as restrições impostas ao eleitor e, consequentemente, a sua participação no processo democrático. $\mathrm{O}$ registro da União Democrática Nacional - UDN como partido político naquele ano obedece, portanto, às determinações dessa legislação (SOUZA, 1983, p.84; GAMA NETO, 1995). ${ }^{1}$

De acordo com o Artigo 109, do Decreto-Lei no 7.856 seria considerado um Partido apenas toda associação de pelo menos dez mil eleitores, de cinco ou mais circunscrições eleitorais que tivessem adquirido personalidade jurídica nos termos do Código Civil. Deste modo, a contragosto de muitas forças locais, no ano de 1945 só foram admitidos partidos políticos de âmbito nacional. Aos partidos regionais dissolvidos pelo Decreto-Lei de 02 de dezembro de 1937 seria permitido filiar-se, em 1945, aos novos partidos nacionais. Ficava vedada, no entanto, a criação de milícias cívicas ou formação auxiliar dos partidos, bem como o uso de uniformes e estandartes (BRASIL, DECRETO 7.586, 1945).

Não obstante essa configuração nacional, em cada estado os rearranjos partidários ocorreram de maneira muito particular, com formulação de alianças que atendiam muito mais à cultura política do estado do que às deliberações do diretório nacional do partido. Na Bahia, a Concentração Autonomista, que desde 1934 era a mais organizada agremiação de oposição a Vargas, abrigou-se na União Democrática Nacional e apoiou o nome do brigadeiro Eduardo Gomes como candidato à presidência da República nas eleições realizadas em 2 de dezembro daquele ano.

Não foi a primeira experiência dessa agremiação política com uma campanha nacional. Em 1937, a Concentração Autonomista ingressou na União Democrática Brasileira - UDB que lançou Armando Sales de Oliveira como candidato a presidente, e mesmo depois do golpe que instaurou o Estado Novo no Brasil naquele ano, a agremiação não deixou de atuar nos bastidores da política, tendo à frente o "eminente baiano" exilado Otávio Mangabeira que do exterior escrevia cartas, manifestos e telegramas combatendo o Governo Vargas. Mangabeira utilizavase, também, do prestígio político que obteve como ministro das relações exteriores no governo de Washington Luís para atuar e fazer campanha contra Vargas e o Estado Novo. Assim, tão

\footnotetext{
${ }^{1}$ Maria do Campello de Souza (SOUZA, 1983, p. 64) também aborda a formação dos partidos na reabertura política de 1945 como um desdobramento da conjuntura internacional entre as democracias liberais e os fascismos. Como ela pretendeu analisar a formação do sistema partidário no Brasil e a relação deste sistema com os Estado, a sua conclusão é de que a queda de Vargas não produziu uma substituição radical dos grupos de poder, embora tenha exigido uma reformulação na política institucional.
} 
logo a legislação eleitoral foi publicada no ano de 1945, os autonomistas baianos ao lado de Otávio Mangabeira, mobilizaram-se para “devolver a Bahia à posse de si mesma". ${ }^{2}$

Para tanto, precisavam superar as dificuldades impostas pela legislação eleitoral. De certo modo, esta legislação dificultava o processo para a organização da oposição e beneficiava os partidos que estavam na base do governo já que estes poderiam contar com a estrutura burocrática para a sua organização. Em razão disso, mesmo antes de o novo Código Eleitoral ter sido aprovado, em maio de 1945, os homens e mulheres que estavam à frente da oposição estadonovista na Bahia já se posicionavam contra a nova legislação eleitoral esboçada desde o final de fevereiro, a exemplo do Ato de $n^{\circ} 9$ (BRASIL, LEI ${ }^{\circ} 9,1945$ ).

Os protestos contra essa lei foram numerosos na Bahia. Partiram, em sua maioria, de intelectuais, advogados e professores universitários, alguns deles ligados à Concentração Autonomista. Entre os argumentos, destacavam-se aqueles que acusavam Getúlio Vargas de beneficiar os políticos que estavam incrustados no aparelho estatal, razão pela qual teriam maiores possibilidades de arregimentar aliados para as bases partidárias que representavam, ou seja, o PSD. Para convencer correligionários de todo o estado seria preciso uma atuação forte e os autonomistas baianos, convertidos em 1945 em udenistas, não pouparam esforços, servindo-se por todo o ano de 1945 do jornal vespertino baiano A Tarde para pontuar as críticas contra o governo Vargas e defender o retorno ao regime constitucional.

\section{Os antecedentes da oposição baiana a Getúlio Vargas}

No ano de 1930, a Bahia foi o último estado do norte a manter-se fiel ao governo de Washington Luís. A Revolução de 1930 chegou ao estado com uma base de apoio político bastante fragmentada. Embora tivesse recebido a adesão de certo número de coronéis do interior do estado, sobretudo por influência do governo mineiro e de alguns militares e civis, em relação à política, dos nomes nacionalmente conhecidos, apenas José Joaquim Seabra e Moniz Sodré se colocaram contra a chapa Júlio Prestes/Vital Soares, sendo o primeiro, o principal responsável pela divulgação da Aliança Liberal no estado baiano.

\footnotetext{
2 A expressão surgiu na época da campanha da Concentração Autonomista contra o PSD local, na qual Otávio Mangabeira e Juracy Magalhães, à época interventor federal no estado, concorriam para o cargo de governador, em 1934. Antes disso, ainda em 1931, já se tinha elaborado a narrativa da Bahia humilhada, pois desde que a Revolução de 1930 foi vitoriosa, o estado baiano não teve nenhum político tradicional indicado para governá-lo. Os políticos baianos depostos naquele ano ressentiam-se dessa não indicação e acusavam a Getúlio Vargas e a Juracy Magalhães de querer "cavalgar o estado".
} 
O movimento revolucionário foi organizado na Bahia em três eixos: o primeiro, sob orientação de Juarez Távora; o segundo, buscando orientação e apoio no Rio de Janeiro; e o terceiro sob controle dos coronéis e comando do governador de Minas Gerais. Ao que parece, faltou uma ação coordenada entre esses "conspiradores" para que o movimento fosse bem sucedido no estado, o que o caracterizou como fraco. ${ }^{3} \mathrm{O}$ fato é que, estando a Bahia situada em ponto estratégico de ligação entre os estados do norte (nordeste) e sul/sudeste do país, era certo que em algum momento marchariam sobre ela os revolucionários de um ou outro eixo, como também era certo que o governo constituído encontrasse aí um ponto estratégico para montar sua base militar e conter as forças mineiras ou os revolucionários que vinham do norte.

Os planos do governo ao arregimentar os coronéis do interior do estado da Bahia era fazer uma investida sobre o norte de Minas Gerais e com isso atrapalhar o avanço dos revolucionários mineiros sobre o Rio de Janeiro. A vigilância sobre esse estado já estava sendo feito há algum tempo, desde que o presidente desconfiara de que os mineiros estavam usando o Porto de Caravelas, na Bahia, para importação de armas (PANG, 1979. p. 208). Com as sucessivas vitórias dos revolucionários no norte, o plano de invasão a Minas Gerais foi cancelado, transferindo-se todo aparato para conter as tropas revolucionárias que vinham do norte e resguardar a capital do estado baiano.

Por outro lado, os revolucionários também já tinham montado a sua base de apoio na Bahia. Além dos militares e grupos políticos essa base estava assentada, também, na figura dos coronéis do interior do estado. Assim, quando a 24 de outubro de 1930, dia em que estava prevista a realização de uma das batalhas mais difíceis do movimento revolucionário no norte e Washington Luís foi deposto na capital do país, o estado da Bahia estava dividido (BARATA, 1978, p 137). De um lado, mangabeiristas e calmonistas desfazendo-se da expectativa de rever um conterrâneo, o vice-presidente eleito Vital Soares, ocupando um posto importante que podia recolocar a Bahia no centro do cenário político nacional e, de outro, seabristas, jornalistas, profissionais liberais e demais dissidentes da oligarquia baiana que desde 1929 vinham fazendo a campanha da Aliança Liberal no estado.

Com a deposição de Washington Luís findava, também, a atuação do baiano Otávio Mangabeira como ministro das relações exteriores. Nos quinze anos que segue à data de sua deposição, Mangabeira colocou-se contra o governo revolucionário, combatendo-o de forma

\footnotetext{
${ }^{3}$ Por outro lado, a história veiculada através das memórias de Juracy Magalhães que dão destaque à atuação militar com ações concentradas entre 22 e 24 de outubro de 1930 encobriu os conflitos já instalados no sul do estado da Bahia desde o dia 10 de outubro de 1930, quando a fronteira baiana foi invadida e "dominada" pelas forças

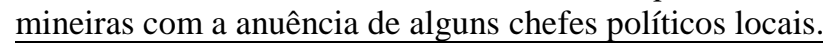


contundente, personificando na figura de Vargas o maior inimigo do Brasil e criando para si e para os seus conterrâneos a imagem de maior defensor da Democracia.

Através de cartas, manifestos e telegramas que marcaram a sua atuação nesse período, Otávio Mangabeira tornou-se uma das maiores lideranças em oposição ao regime Vargas, alinhando-se a ele, inclusive, os homens que defenderam a Aliança Liberal na Bahia nos anos de 1929 e 1930, a exemplo de Seabra e os dissidentes do governo Vargas após a instalação do Estado Novo, a exemplo do próprio Juracy Magalhães que de 1931 a 1937 assumiu, contra todos os protestos de Otávio Mangabeira, a interventoria federal no estado da Bahia.

A análise desses primeiros anos de atuação de Otávio Mangabeira como oposição a Vargas é objeto de uma discussão que não cabe nos limites desse artigo. Porém, vale ressaltar que a sua atuação nos bastidores da política baiana e nacional sempre foi constante, especialmente entre os anos de 1932 e 1935, período que compreende, respectivamente, a revolução constitucionalista de 1932, a previsão do retorno do primeiro exílio, a elaboração da constituinte, o retorno do exílio e a atuação enquanto membro da minoria na Câmara de Deputados, em função de sua eleição pelo estado da Bahia no pleito de 1934. Em 1937, intensificou a oposição durante a campanha presidencial quando atuou como principal articulador da campanha da UDB, interrompida pelo golpe de 10 de novembro que instalou o Estado Novo no Brasil e, posteriormente, em 1945, no declínio do regime quando, desde o exílio, se articulava nas bases de formação da UDN liderando no estado baiano a campanha em favor do brigadeiro Eduardo Gomes e recuperando, ao modo da campanha da Concentração Autonomista de 1934, o lema "pela desumilhação da Bahia" e pela "devolução da Bahia à posse de si mesma".

\section{A fundação da UDN nacional e a Concentração Autonomista como diretório baiano}

Conforme destacamos, essa não foi a primeira experiência dos autonomistas com a organização de um Partido Nacional. Durante a campanha presidencial de 1937, os autonomistas envolveram-se com a fundação da União Democrática Brasileira, a UDB, que teve um tempo curto de atuação na campanha de Armando Sales de Oliveira e que, tal como a UDN, em 1945, abrigava agremiações partidárias de vários estados do Brasil, somando um total de vinte e oito partidos estaduais, bem como contava com Otávio Mangabeira à frente da 
campanha presidencial. ${ }^{4}$ No pleito eleitoral de 1945 , portanto, seriam retomadas as tarefas interrompidas pelo golpe de 10 de novembro de 1937.5

O registro da União Democrática Nacional como Pessoa Jurídica foi feito em 28 de agosto de 1945, no Cartório de Títulos e Documentos - 5ºfício - Alfeu Felicíssimo, no Rio de Janeiro. No Tribunal Superior Eleitoral - TSE, a UDN só protocolou o pedido de registro provisório em 18 de setembro de 1945. Um mês depois, em 17 de outubro, solicitou o registro permanente, com a apresentação das listas dos respectivos correligionários nos Estados. Àquela altura, estava representada por 16 estados mais o Distrito Federal. No que diz respeito à Bahia, consta, na petição, o número de 34 listas com quatrocentos e noventa e uma assinaturas. $\mathrm{O}$ registro definitivo pelo TSE foi emitido apenas pela Resolução 291, de 31 de outubro daquele ano.

No Tribunal Regional Eleitoral da Bahia, o registro da União Democrática Nacional só foi publicado no Boletim Eleitoral, do Diário Oficial do Estado, no dia 31 de novembro de 1945, apenas dois dias antes das eleições. Na mesma data foram publicados também os registros do Partido Social Democrático, Partido Republicano Democrático, Partido Popular Sindicalista, Partido de Representação Popular, Partido Comunista do Brasil e Partido Trabalhista Brasileiro. Os demais partidos nacionais registrados à época não dispunham de representação formal na Bahia.

\footnotetext{
${ }^{4}$ Partidos regionais que formavam a UDB: Partido Trabalhista Amazonense e Partido Radical Republicano do Amazonas, do estado da Amazonas; Frente Única, do Pará; Partido Social Democrático, do Ceará; Aliança Social, do Rio Grande do Norte; União Democrática Espiritosantense e Partido da Lavoura, do Espírito Santo; Aliança Autonomista Fluminense e Partido Social Democrático do Estado do Rio, no Rio de Janeiro; Partido Constitucionalista, de São Paulo; União Republicana Paranaense e o Partido Liberal, do Paraná; Legião Republicana Catarinense e Partido Republicano Liberal, de Santa Catarina; Partido Republicano Liberal do Rio Grande do Sul, Partido Republicano Castilhista e União Democrática Nacional, do Rio Grande do Sul; Partido Republicano Matogrossense, no Mato Grosso; Partido Republicano Mineiro e Partido Progressista Democrático, em Minas Gerais; Partido Libertador Carioca, Partido Republicano do Distrito Federal, Partido Popular Democrático, Partido Libertador Carioca, Partido Evolucionista e Núcleo Eleitoral Pró-emancipação Carioca, no Distrito Federal; Concentração Autonomista, da Bahia. Assinou pela Bahia o advogado/deputado Luiz Viana. A Batalha, Rio de Janeiro, 16 de julho de 1937 p. 2. Disponível em: <memoria.bn.br>. Acesso em: 05.05.2016.

${ }^{5}$ O Jornal a A Razão, do Rio de Janeiro também registrou o nascimento da UDB: "Registrada a UDB" - O Superior Tribunal Eleitoral concedeu registro à União Democrática Brasileira como partido de âmbito nacional. Jornal $A$ Razão, 26 de agosto de 1937. n. 370. Ano II. Três dias depois, o mesmo jornal publicou que a UDB teria aberto a semana de alistamento, esperando registrar 40.000 mil eleitores. Pouco menos de um mês, é o mesmo jornal que também noticia o fim do incipiente partido. Na matéria "Morte Prematura" afirma: "agita-se a União Democrática Brasileira nos estertores da agonia. Nenhum médico poderá salvá-la da morte inevitável que se aproxima com a rapidez dos meteoros aos ruídos das turbulentas alegrias ameriquistas. O golpe foi fatal: quebrou-lhe a espinha dorsal com a renuncia do sr. Flores da Cunha. Arrastando-se cambaleando e trôpega, restam-lhe apenas alguns melancólicos dias de vida. Antônio Carlos, Otávio Mangabeira, Artur Bernardes, João Carlos Machado e outros membros da sua desditosa família-velha alcoviteira, no espasmo das dores insuportáveis, amaldiçoando o destino ingrato com o rictus sinistro dos condenados. Pobre UDB! Extinguiu-se tão cedo, quando ainda ressoam nos ouvidos majoritários os ecos pirotécnicos do seu contentamento infantil naquela noite traquinas do Campos da América...”. A Razão, 24 de outubro de 1937, p.3. Disponível em: <memoria.bn.br>. Acesso em: 04.05.2016.
} 
Não obstante essa proximidade do registro com o pleito eleitoral a 02 de dezembro, a UDN já era uma legenda conhecida pelos baianos desde o início do ano. Como "frente ampla" de oposição, foi fundada no dia 07 de abril de 1945, e a sua formação foi "menos um fato, do que um processo histórico" (FRANCO, 1974, p. 31). A UDN foi fruto da desarticulação de um período no qual Getúlio Vargas exercia hegemonia e converteu-se em ponto de reunião para onde iam todos aqueles que contra ele pretendiam lutar (IDEM, p.87).

Pensada ainda no ano de 1943 pelo ex-ministro e ex-deputado baiano Otávio Mangabeira, exilado em Nova York, e Armando Sales, em Buenos Aires, entre outros políticos que se opunham a Vargas, a UDN abrigou um grupo heterogêneo. Integravam esse elenco inicial políticos das mais diversas categorias, motivo pelo qual, ainda no decorrer de 1945 “formalizaram-se as dissidências, trazendo às claras a característica da 'frente ampla' que marcara a criação do partido" (BENEVIDES, 1981, p.47).

Os autonomistas baianos, conforme assinalamos, fizeram parte do primeiro grupo que ingressou na UDN no ano de 1945. A demora em organizarem-se como diretório na Bahia, o que só veio ocorrer em finais de outubro daquele ano, é muito mais fruto das determinações do código eleitoral já mencionado, que impôs restrições na estruturação partidária da oposição, do que da falta de representação da agremiação no estado.

No dia $1^{\circ}$ de março de 1945 o jornal A Tarde, principal porta-voz desse grupo de oposição, publicou uma matéria intitulada "Esboço de Programa da União Democrática Nacional: movimentam-se as forças políticas para arregimentação das oposições" (A TARDE, 01.03.1945, p.2). A matéria de origem carioca divulgava os princípios gerais para a arregimentação da oposição no país. Segundo o texto, considerando a necessidade de defender, em todo o Brasil e para todos os brasileiros, o regime democrático e a sua prática efetiva, os partidos de correntes democráticas progressistas nacionais teriam proclamado alguns princípios para orientar a ação política em 1945, entre eles, o retorno do regime representativo, o sufrágio universal por voto secreto e direto, e, finalmente, as liberdades de pensamento, organização partidária e união sindical. A UDN tornou-se o partido representante destas correntes.

Era, portanto, o esboço de um programa que só se afirmaria mais tarde, mas ainda que o seu registro definitivo tenha enfrentado as dificuldades burocráticas do TSE e saído somente a 30 de outubro de 1945, desde abril, a UDN baiana atirava-se em comícios por toda a Bahia.

\section{Os Udenistas baianos e as críticas à legislação eleitoral de 1945}


Dois dias antes da divulgação desses princípios gerais da UDN, no Rio de Janeiro, o presidente Getúlio Vargas promulgou o Ato Adicional de nº 9, em 28 de fevereiro de 1945, fixando prazo para marcar a data das eleições e estabelecendo regras para o processo de democratização do país. Entre os críticos baianos, estavam os professores Jaime Aires e Nelson Sampaio, ambos na oposição a Getúlio Vargas desde o início da década de 1930 quando despontaram como jovens lideranças políticas. Para Jaime Aires nunca o povo havia sido tão provocado quanto o teria feito Getúlio Vargas no poder. Aquele Ato afrontava o povo brasileiro e mantinha o parlamento como um "pobre e melancólico fantoche" sem perspectivas de mudanças no futuro. O Ato, portanto, pretendia "subtrair a uma grande nação o direito de dispor de si mesma e até do seu porvir e dos seus destinos (A TARDE, 3.3.1945, p.2).

Nelson Sampaio, que fez a campanha revolucionária no estado baiano e que, ao lado de Seabra, afastou-se do governo Vargas ainda em 1931, tendo sido perseguido por Juracy Magalhães à época da Revolução Constitucionalista, momento em que foi preso, surrado e deportado da Bahia para o Rio de Janeiro, questionava: o Ato“[...] foi remédio suficiente para curar a doença do fascismo que a Carta de 37 trouxe do berço?" Para ele, as determinações impostas pelo Ato Adicional, tais como a instituição de eleições diretas para presidente e membros do parlamento (deputados e senadores), o aumento do número de deputados federais para cada estado, a abolição de conselheiros federais nomeados pelo presidente da república, a supressão da prerrogativa do presidente para nomear um ministro para presidir o Conselho de Economia Nacional e a diminuição do número de condições para ser eleito membro do Conselho, não descaracterizavam em nada as prerrogativas absolutistas que a Carta de 37 conferiram ao presidente. Pelo contrário, davam-lhe novas, especialmente porque mantinham a estrutura do poder legislativo com a mesma precariedade. Concluiu, portanto, que o Ato teria guardado a "medula fascista" da Constituição de 37, com a singular situação de "um indivíduo investido do poder de dissolver o tribunal que o vai julgar” (IDEM, p.2).

Dois dias depois, o jornal abriu espaço para a opinião de mais um baiano, Jaime Baleeiro. Este, assim com os seus conterrâneos, endossou o caráter pouco transformador do Ato de $n^{\circ}$ 9. Afirmou que ele calava em relação às garantias e liberdades de palavras, de reunião e de pensamento e, assim como Nelson Carneiro, destacou o papel de cerceador da justiça do parlamento que continuava no Ato (A TARDE, 05.05.1945, p.2).

O professor Orlando Gomes, na mesma edição, caracterizou o Ato como refinamento da seiva autoritária: “[...] Revela, em primeiro lugar, desconhecimento completo da realidade 
internacional. Trai as esperanças e aspirações democráticas do povo brasileiro. Aponta a consciência jurídica da nacionalidade [...] sem qualquer alteração do 'aleijão' constitucional abortado há mais de sete anos" (IDEM). Na sua análise, Orlando Gomes tocou numa questão crucial que era a manutenção do princípio corporativo. Para ele, esse dispositivo do Ato, entre outros empecilhos à democracia, autorizava ao governo a edição de normas reguladoras dos contratos coletivos de trabalho, ou seja, o Ato lhe dava o direito de intervir na economia do país e isso significava, concretamente, dispor de "um tremendo instrumento de coação sobre a burguesia e o proletariado" (IBIDEM).

Berbet de Castro, ex-procurador geral do estado da Bahia, também analisou o Ato Adicional de $\mathrm{n}^{\circ}$ 9. Para ele, o documento impedia que a reforma fosse efetivamente realizada no Brasil, pois não previa trâmite livre para todo e qualquer projeto que fosse apresentado pela Câmara de Deputados, ao contrário daqueles apresentados pelo poder executivo que podiam ser votados, inclusive em blocos, por maioria ordinária. Acrescentou ainda, que o Ato negava o direito ao voto aos soldados e suboficiais brasileiros, não tratava da questão da anistia e submetia as eleições ao "império e à direção da ditadura", previamente assegurando "a eleição do Sr. Getúlio Vargas (...) garantindo-se-lhe, no Parlamento, uma maioria que lhe permita fazer valer, ali, a sua vontade" (IBIDEM).

Outras análises e críticas se estenderam ao Ato de $n^{\circ} 9$ até que as atenções fossem desviadas para a elaboração do novo Código Eleitoral. Na imprensa baiana de cunho liberal priorizava-se apontar as divergências entre os integrantes da Comissão de Elaboração do Código. Em matéria datada de 27 de abril de 1945, no jornal A Tarde, destacavam-se informações sobre divergências entre José Linhares e Vicente Piragibe (A TARDE, 27.04.1945, p. 2). No dia 07 de maio, divulgava-se o debate que ocorreria entre advogados acerca daquela lei. Segundo consta, teriam sido convidados advogados militantes do Foro, entre os quais estavam “João Mangabeira, Hermes Lima, Castro Rabelo e Pinto Lima, além de outras figuras de projeção na advocacia" (A TARDE, 07.05.1945, p.2).

No processo de elaboração do novo Código Eleitoral, previsto para lançamento em até noventa dias decorridos da promulgação do Ato em fevereiro, foram numerosas as sugestões feitas pela comunidade jurídica e política do Brasil. A UDN, por exemplo, preparou várias emendas à nova lei. Entre as sugestões do Partido destacaram-se a suspensão das limitações impostas pelos estados de guerra e de emergência, excetuando-se o interesse da segurança externa; a atribuição às Casas do Parlamento para elaborar a Constituição da República; a negação de registro aos partidos que, nos seus programas, atentavam ao sistema democrático 
republicano; o voto universal; voto para os inferiores das classes armadas e para todos os civis convocados, incluindo a FEB; o registro e limitação das verbas eleitorais; a proibição aos jornais e rádio do governo incorporado ao patrimônio da União de fazerem propaganda de partido ou candidatos; seis meses para as desincompatibilizações; e, finalmente, licenciamento das respectivas corporações para os candidatos militares (A TARDE, 9.5.1945, p. 2).

Conforme a matéria do jornal, Agamenon Magalhães teria recebido e analisado 688 emendas ao novo código (IDEM). No entanto, de acordo com o parecer de Odillon Braga, extitular da pasta de Agricultura, nenhuma das sugestões feitas pela UDN teria sido acatada e o ministro teria trabalhado, inclusive, para piorar as disposições do Código (IBIDEM). Entre as denúncias, Odilon Braga afirmava que o Código vedava o pronunciamento eleitoral das massas que habitavam os territórios brasileiros como Fernando de Noronha, Amapá, Guaporá, Ponta Porã e Uguassu e ainda dava lugar a fraude, pois ao equiparar carteiras profissionais aos antigos títulos eleitorais alterava as regras de representação profissional e fortalecia o voto presidencial. A UDN, através dos seus juristas iria, portanto, denunciar a nova lei e para isso contaria com a ajuda imprescindível da imprensa.

Somavam-se às críticas de intelectuais e políticos de outros estados e da Bahia, a fala do representante baiano que mais se destacava no cenário da oposição nacional: Otávio Mangabeira. Desde que tinha regressado ao Brasil, em 11 de maio de 1945, Otávio Mangabeira envidava esforços para combater o governo constituído. Em relação às disposições do Código, o baiano afirmava que o interesse maior de sua promulgação era o embaraço do processo eleitoral. Apostava, no entanto, que as vantagens legadas ao PSD pela legislação não seriam capazes de vencer o anseio popular. Otávio Mangabeira dizia acreditar no poder miraculoso dos grandes movimentos de opinião quando era o povo que entrava em cena. Segundo entrevista concedida ao jornal A Tarde,

Todos juntos dirigirão a campanha. Trata-se de uma campanha cívica como a da independência, da abolição e da República. Campanha de libertação nacional $[\ldots]$. A nova democracia brasileira precisa ser realmente do povo. Temos tido democracia de elites. Temos duas espécies de massas: das cidades e zonas limítrofes e a grande massa amorfa e totalmente abandonada. Acredito que a democracia fundada no voto livre perderá a preocupação eleitoral para ser a democracia do povo, da grande massa que no Brasil, vive morrendo de fome, batida pelas doenças atrasadas de séculos (A TARDE, 29.05.1945, p.2).

Com esta perspectiva, anunciava que a UDN pretendia formar um grande movimento de opinião sob a bandeira Eduardo Gomes. Contando com a imprensa, a mocidade, os 
intelectuais, a Sociedade Amigos da América, elementos da esquerda, proletários e o elemento feminino, Otávio Mangabeira acreditava na vitória do seu candidato no estado da Bahia.

Fica evidente que Mangabeira voltou a atenção para um grande contingente de trabalhadores, homens e mulheres que votariam pela primeira vez, bem como para os servidores públicos que, segundo ele, tinham sofrido muito com a inflação altíssima e o congelamento de salários durante o governo de Getúlio Vargas. Àquela altura, os movimentos de massa já dispunham de um razoável poder sobre os dirigentes políticos ou ao menos estabeleciam relações de troca de forma bastante diferenciadas daquela dos anos iniciais da década de 30 . Não era prudente deixar a expressão "povo" de fora das falas e dos programas partidários.

Por outro lado, a proibição pelo Código do registro e funcionamento de Partidos que fossem contrários aos princípios democráticos, impunha obstáculos às agremiações partidárias como o PCB e o PSB (Esquerda Democrática). O PCB, que com bastante dificuldade conseguiu o registro, apoiou, em sua maioria, o candidato Gaspar Dutra, mas a Esquerda Democrática que malogrou nessa empreitada, abrigou-se sob o guarda-chuva da UDN. Era preciso, portanto, atender às aspirações desse grupo.

Para os udenistas/autonomistas baianos, ainda que o Código Eleitoral restringisse a participação política de parte significativa da população brasileira maior que dezoito anos, ao proibir o voto de analfabetos, militares em serviço ativo e mendigos, além de desobrigar as mulheres que não exerciam profissão lucrativa de votar, poderia canalizar para as hostes do governo, parte expressiva daqueles que seriam qualificados para o sufrágio tomando por base o registro profissional, mediante o dispositivo ex-offício.

Nesse aspecto, a tarefa da UDN era grande. Formada em sua maioria por bacharéis, o Partido não conseguia uma inserção plena na classe trabalhadora. Sua bandeira de representantes honestos e defensores da democracia não parecia satisfatória ao povo brasileiro, no ano de 1945. Os partidos que pleiteavam o apoio das camadas populares precisavam oferecer muito mais que o discurso da liberdade, sobretudo, porque para a maioria da população, a primeira forma de participação no estado havia se dado com a legislação trabalhista do governo Vargas, razão pela qual ainda era forte a sua base de apoio popular (GOMES, 2013, p, 176188). ${ }^{6}$

\footnotetext{
${ }^{6}$ Segundo Francisco Weffort, “(...) para as massas populares a legislação do trabalho significará a primeira forma através da qual elas verão definida sua cidadania, seus direitos de participação nos assuntos do Estado, e será também um dos elementos centrais para entendermos o tipo de aliança que passarão a estabelecer com os grupos dominantes através dos líderes populistas. (WEFFORT, 1980, p.66).
} 
Por outro lado, os partidários de Getúlio Vargas no estado da Bahia afirmavam que os liberais tentavam angariar o apoio das massas com promessas supérfluas colocando em plano muito inferior aquilo que identificava como a primeira de todas as liberdades, a econômica. A única que, "verdadeiramente, libertava a criatura da condição humana de escravidão e escravisamento". Divulgavam para o eleitorado baiano que diferente destes homens que espalhavam falsas expectativas, o presidente Getúlio Vargas não "acenava com promessas utópicas e, corajosamente, afirmava o primado do econômico sobre o político". Para os partidários de Vargas, a sua bandeira era a da liberdade com maiores oportunidades. Com reformas sociais de grande envergadura, Getúlio Vargas seria o único líder autêntico que se dirigia às massas populares com reivindicações norteadas pelo direito e a justiça (DIÁRIO DA TARDE, 19.1.1945, p.3).

Não era tarefa fácil para os udenistas combaterem os discursos dos pessedistas que defendiam a candidatura de Gaspar Dutra e convencerem os setores médios e a incipiente classe trabalhadora que exerceriam o direito ao voto pela primeira vez a aderir aos seus ideais. A situação parecia complicar-se, sobretudo porque, além do PSD, partido situacionista, concorriam às eleições de 1945 os recém-fundados Partido Trabalhista Brasileiro, o PTB e o Partido Comunista do Brasil, o PCB, legalizado naquele ano e que, na competição interpartidária, entrou na disputa pelos votos do incipiente operariado baiano, especialmente aqueles fixados nas pequenas indústrias e na rede ferroviária e demonstrou grande potencial eleitoral na Bahia (SENA JUNIOR, 2009).

Já que a estrutura partidária imposta pelo Código não ajudava o Partido e os discursos eleitorais não alcançavam às massas de imediato, era preciso investir em medidas bastante conhecidas pelos dirigentes udenistas: apoiar-se nas forças políticas regionais do estado. Conforme apontou Paulo Santos Silva, a estrutura política local ainda teve peso na formação dos partidos nacionais naquele ano. Naquele processo eleitoral, a aspiração de retomar as práticas políticas da República Velha que foram suprimidas pela Revolução de 1930, ainda que fossem no plano do discurso, ensejaria a hipótese da sua materialização na organização e na atuação partidária subsequente (SILVA, 2001).

Desse modo, era preciso apostar no apoio regional e apostar também nos desentendimentos e deserções nas hostes situacionistas. Enquanto Renato Pinto Aleixo, interventor federal na Bahia, ainda não havia conseguido o apoio de Pacheco de Oliveira e lidava com a perda de Geraldo e Francisco Rocha, da família do coronel Franklin Lins de Albuquerque e outras tantas forças políticas locais que temiam seguir um interventor que a 
priori, tinha prazo de validade, os udenistas ganhavam os municípios na tentativa de angariar votos com a seguinte justificativa:

[...] Quem vai seguir Pinto Aleixo nas próximas eleições? O bravo militar é político a prazo fixo. Termina com as eleições. Nos quadros que se formarem depois de 2 de dezembro, seu nome não se incluirá entre os dos condutores. Ninguém se decide a obedecer a um comandante que já se sabe abandonará o seu exército ao dobrar a primeira esquina [...] "O ambiente sombrio que se respirava no palácio da Aclamação não podia ser atribuído ao general Pinto Aleixo, mas, sim, a transitoriedade da carreira política (A TARDE, 12.06.1945, p.3).

Com essa justificativa, os udenistas baianos fundaram vários diretórios municipais “com manifestações recebidas de todas as classes sociais". Nestor Duarte e Luiz Viana, membros da Comissão Executiva da Concentração Autonomista viajaram pelos municípios de Serrinha, Euclides da Cunha, Uauá, Campo Formoso, Bonfim, Juazeiro, Inhambupe, Cipó, Alagoinhas, Curaçá, Jandaíra, Irará, Cairú, Brejões e outras tantas cidades onde se organizaram comícios. Ambos declararam-se muito satisfeitos com as "impressões colhidas dos entendimentos mantidos com os elementos oposicionistas locais", assinalando o grande entusiasmo existente em toda a região percorrida em relação às futuras eleições e afirmando ser intenso o serviço de alistamento de eleitores (A TARDE, 15.6.1945, p.3).

Acreditavam ou queriam transmitir a ideia de que era geral a simpatia popular pela candidatura do brigadeiro Eduardo Gomes, cujo nome teria votação capaz de surpreender os mais otimistas, pois, além do apoio de elementos independentes de todas as classes, a candidatura contava com a determinação de chefes de maior prestígio naqueles municípios (A TARDE, 2.8.1945, p. 2).

Juraci Magalhães dava também a sua contribuição ao enviar telegramas para diferentes lideranças políticas, com claro objetivo de exercer a influência que ainda possuía em vários municípios da Bahia (DIÁRIO DA TARDE, 20.6.1945). A aliança entre Otávio Mangabeira e Juracy Magalhães, no entanto, não foi aceita por alguns correligionários políticos, especialmente os que compunham o antigo Partido Republicano e que acompanharam J.J. Seabra, à época já falecido, na oposição a Vargas e ao próprio Juracy Magalhães na década anterior. Sobre essa aliança o filho de J.J Seabra ressaltava:

Considero uma vergonha a união com o sr. Juraci Magalhães de cujo governo sinistro a Bahia guarda ainda hoje as mais penosas recordações. O governo Juraci foi violência e fraude. Ele atentou contra todas as liberdades: a de reunião, a de imprensa, a de pensamento, a de voto livre e até, contra a própria existência dos seus adversários [...]. Estou solidário com os meus amigos que 
na política federal se acham integradas com as forças políticas que apoiam o presidente Getúlio Vargas e na Bahia deram a sua solidariedade ao general Renato Pinto Aleixo (DIÁRIO DA BAHIA, 9.3.1945).

Foram muitos os municípios que receberam as caravanas autonomistas/udenistas naqueles meses de campanha. $\mathrm{O}$ principal objetivo era engrossar a lista de correligionários e garantir a vitória nas urnas. E nesse ritmo frenético de busca de apoio nos municípios, a UDN, ao final de novembro de 1945 contava com diretórios em 137 municípios, contra 130 em favor do seu principal adversário, o PSD (BAHIA, DIÁRIO OFICIAL, 30.11. 1945).

Esse panorama não nega a máxima de um dos fundadores da UDN que afirmou que se ela tinha a cabeça nas cidades, entre os intelectuais urbanos, seu corpo estava, em grande parte, no eleitorado rural e semi rural (ARINOS, p.85). O interior da Bahia oferecia ao maior chefe udenista baiano um expressivo contingente eleitoral. Otávio Mangabeira era a liderança baiana de oposição de maior destaque, com ele votavam todos aqueles autonomistas apeados do poder durante a Revolução de 1930, os homens que se afastaram do governo no decorrer da década de 1930 e as novas lideranças políticas que surgiram naquele contexto.

O entusiasmo dos baianos em torno de Otávio Mangabeira era justificado pela possibilidade de mais uma vez a Bahia ser elevada a um posto de destaque da política nacional, o que ocorreu quando ele foi alçado ao cargo de presidente da UDN. Assim, para que a vitória se consumasse, caberia aos líderes autonomistas da capital conquistar o eleitorado do interior. Portanto, "as atividades intelectuais dividiam-se com a sôfrega caça aos votos, principalmente do disputado eleitorado rural e semirrural" (SILVA, 2011, p.47-49).

Mas a adesão de prefeitos às hostes udenistas era muito difícil. Desde março de 1945, o interventor Pinto Aleixo mobilizava os representantes do interior, convocando-os a apoiar a candidatura de Gaspar Dutra em troca de benesses. Posteriormente, com a queda de Getúlio Vargas, em 29 de outubro de 1945, a assunção da presidência por José Linhares e a nomeação de Bulcão Viana para assumir o governo da Bahia, expandia-se a possibilidade de a oposição se fortalecer em alguns municípios, tendo em vista que alguns prefeitos foram substituídos. Ainda no final daquele ano, o Decreto de $\mathrm{n}^{\circ} 8.188$, de 20 de novembro, afastou dos cargos até 3 de dezembro de 1945 todos os prefeitos municipais que eram membros de diretórios de partidos políticos. Em seus lugares, os juízes de direito vitalício responderiam pela prefeitura até as eleições, mas já não havia tempo suficiente para investir em novas alianças.

Apesar do esforço, buscar apoio nas forças regionais não foi suficiente para garantir a vitória de Eduardo Gomes nas eleições de 2 de dezembro de 1945, menos ainda, a tentativa de caracterizar a campanha como popular. Primeiro, não foi possível contar com a presença de 
Otávio Mangabeira nos comícios baianos, salvo o de 27 de julho, em comício realizado em Salvador. Desde o retorno a 11 de maio de 1945, Otávio Mangabeira envolveu-se com a campanha do brigadeiro em todo o território nacional, mas priorizou as atividades ocorridas na região sul e sudeste. Seu contato com os baianos foi feito quase sempre pelo jornal $A$ Tarde. Certamente, essa ausência contribuiu para que muitos eleitores não aderissem às hostes udenistas.

Segundo, como já destacamos, os autonomistas, agora udenistas, enfrentaram além do PSD, cuja organização era semelhante à de 1930, portanto, relativamente conhecida, os recémcriados PTB e PCB, que entraram na disputa pelos votos dos trabalhadores. A votação expressiva de ferroviários no município de Alagoinhas/BA, reduto eleitoral de Otávio Mangabeira, ao deputado Carlos Marighella, candidato a deputado pelo PCB no pleito eleitoral de 1945, é um exemplo do desafio que a UDN enfrentou no diálogo com esse segmento. Não por acaso, o jornal A Tarde, porta-voz dos udenistas da Bahia, além de publicar numerosas matérias defenestrando o governo de Getúlio Vargas e o Estado Novo, intensificou, também, o discurso anticomunista, sobretudo no período mais intenso da campanha eleitoral de 1945 (SENA JUNIOR, 2009, p. 246).

Mas se os resultados dessa empreitada no estado da Bahia não surtiram o efeito desejado, não foi somente pelos embaraços impostos pela legislação eleitoral daquele ano e pelo número e qualidade dos concorrentes, como também, pela própria aura do candidato apresentado pela oposição. Em carta enviada a Mário Alves, do Correio da Manhã datada de dezembro de 1945, Otávio Mangabeira justificou a derrota udenista na Bahia. Para ele, o primeiro obstáculo foi a escassez do tempo para a campanha, 29 de outubro a 02 de dezembro; e o segundo dizia respeito aos métodos. Enquanto o Brigadeiro Eduardo Gomes teria primado "pela nobreza dos processos", o seu adversário teria adotado a calúnia, o que lhe trouxe resultados práticos. Segundo Otávio Mangabeira, duas falsidades teria corroborado para o insucesso da campanha de Eduardo Gomes na Bahia. A de que ele se opunha aos negros e a de que seria infenso ao emprego das mulheres em repartições e serviços públicos. Somou-se a isso, a votação cerrada de católicos contra ele, o que para Mangabeira era uma ofensa ao "católico perfeito” que Eduardo Gomes era (MANGABEIRA, CARTA DO EXÍLIO, 1945).

De fato, num estado formado por uma população predominantemente negra ou afrodescendente, esses "boatos" podem ter repercutido mal para a campanha. Em carta, também de dezembro de 1945, Carlos Olímpio, correligionário da cidade de Alagoinhas, que desde 1934 estava ao lado dos autonomistas, escreveu a Otávio Mangabeira relatando a sua impressão 
acerca das eleições. Apesar de admitir que alcançou um número grande de legendas, encerra: "Escrevo-lhe ainda atordoado das pauladas recebidas nas eleições, vibradas pelos frades, vigários, comunistas, integralistas, passadistas [sic], etc." A cidade que abrigava um volume considerável de ferroviários parecia testemunhar o quão longe das classes trabalhadoras estavam os udenistas/autonomistas baianos, como de resto a União Democrática Nacional em todo o país (MANGABEIRA, CARTA DO EXÍLIO, 12.12.1945).

Passada a eleição era preciso superar a derrota das urnas e se fortalecer para as próximas batalhas. Se a candidatura de Eduardo Gomes não conferiu vitória aos udenistas, era preciso superar a narrativa do derrotismo que se espalhava admitindo, ao menos, a vitória da democracia. Para Otávio Mangabeira, o povo brasileiro devia a Eduardo Gomes a sua libertação e a restituição do seu direito ao voto. O Brigadeiro teria entrado e saído da campanha com a imagem imaculada e com direito à gratidão geral dos seus compatriotas. Exigir mais de uma eleição, nas condições que foram colocadas por Getúlio Vargas, era exigir demais. Por ora, bastava que a máquina democrática tivesse voltado a funcionar. Restava agora, conforme lhe aconselhou Afrânio Coutinho, a vigilância constante (MANGABEIRA, CARTAS DO EXÍLIO, 1612.1945).

Derrotados nas urnas, os autonomistas/udenistas baianos estavam cientes de terem fechado um ciclo iniciado no estado com a Revolução de 1930. Otávio Mangabeira certamente tinha consciência do papel que exercera para a aglutinação dessa oposição durante os quinze anos do governo Vargas, sobretudo com a escrita de manifestos marcados pela defesa da democracia e do liberalismo e recuperados, naquele ano, com vistas a "subtrair o crédito político do Estado Novo e desmoralizá-lo (SILVA; SENA JUNIOR, 2008, p. 123). Para os udenistas, o Brasil não podia se colocar contra o curso dos acontecimentos históricos e os ventos da democracia que sopravam varrendo os regimes autoritários em todo o mundo (FERREIRA; DELGADO, 2013, p. 136).

Por tudo que foi dito, Otávio Mangabeira representava o símbolo desse discurso liberal no estado da Bahia. Assim, ainda que o brigadeiro Eduardo Gomes não tivesse vencido as eleições em seu estado, Mangabeira comemorava a vitória da democracia pela qual esteve, desde 1930, visceralmente empenhado.

\section{Fontes}

A Batalha, Rio de Janeiro, 16 de julho de 1937 p. 2. Disponível em: <memoria.bn.br>. Acesso 05.05.2016. 
A Razão, Rio de Janeiro, 26 de agosto de 1937. n. 370. Ano II. Disponível em: <memoria.bn.br>. Acesso 05.05.2016.

A Razão, Rio de Janeiro, 24 de outubro de 1937, p. 3. Disponível em: <memoria.bn.br>. Acesso 05.05.2016.

A Tarde, Salvador, 05 de setembro de 1945, p. 3.

A hora do estouro. A Tarde, Salvador, 03 de agosto de 1945, p. 2.

A Consciência Jurídica baiana contra o Ato Adicional: é geral a repulsa ao fortalecimento da ditadura. A Tarde. Salvador, 05 de março de 1945, p. 2.

BAHIA, Diário Oficial, Salvador, 30 de novembro de 1945.

Carta de Otávio Mangabeira a Mário Alves. OM 4541 / ap 1945.12.00. S.d. (man.) Fundação Pedro Calmon. Centro de Memória. Arquivo Otávio Mangabeira. Cartas do Segundo exílio.

Carta de Carlos Olímpio a Otávio Mangabeira. OM 97 / cp 1945.12.12 Fundação Pedro Calmon. Centro de Memória. Arquivo Otávio Mangabeira. Cartas do Segundo exílio.

Carta de Afrânio Coutinho a Otávio Mangabeira. OM 415 / cp 1945.12.16. Fundação Pedro Calmon. Centro de Memória. Arquivo Otávio Mangabeira. Cartas do Segundo exílio.

Debate dos advogados em torno da lei eleitoral. A Tarde, Salvador, 7 de maio de 1945, p. 2.

Decreto-Lei $n^{\circ}$ 7.586/1945. Disponível em: <http://www2.camara.leg.br/legin/fed/declei/19401949/decreto-lei-7586-28-maio-1945-417387-publicacaooriginal-1-pe.html>. Acesso em: 25.08.2016.

Entrevista de Carlos Seabra. Diário da Bahia, Salvador, 9.03.45 p. 1 a 8.

Esboço do programa da União Democrática Nacional. A Tarde, Salvador, BA. 1.3.1945, p. 2.

Excursão ao nordeste. A Tarde, Salvador, 02 de agosto de 1945, p. 2.

Liberdade com oportunidade. MUNIZ, Heitor. Jornal Diário da Tarde, Ilhéus, 19 de janeiro de 1945. Ano XVII. num. 1974, p.3.

Lei de ${ }^{\circ}$ 9, de 28 de fevereiro de 1945. Altera a Constituição Federal de 1937. Disponível em <http://www.planalto.gov.br/ccivil_03/LEIS/LCT/LCT009.htm>. Acesso em: 25 de agosto de 2016.

MANGABEIRA, Otávio. A hora dos ditadores já passou, chegou a hora do povo. A Tarde, Salvador, Bahia, 06.03.1945, p.2.

Organização do diretório da UDN na cidade de Areia. A Tarde, Salvador, 15 de junho de 1945, p.3; 01 de agosto de 1945, p. 2. 
Provoca Protestos o Ato Adicional. A Tarde. Salvador, 03 de março de 1945, p. 2.

Repudiado pelos seabristas o sr. Juracy Magalhães. Diário da Bahia, Salvador 14.3.1945. p. 2.

Telegrama de Juraci para os próceres. Jornal Diário da Tarde. Ilhéus, 20 de junho de 1845. p. 2 .

Pesquisa de no 761/2016 - Secretaria de Gestão da Informação do Tribunal Superior Eleitoral. <http://www.tse.jus.br/partidos/partidos-politicos/registros-de-partidos-politicos-1945-a1979>. Acesso em 25.8.2016.

Violências no interior do estado. A Tarde, Salvador, 27 de abril de 1945, p.2.

\section{Referências}

BARATA, Agildo. Vida de um revolucionário: memórias. 2 ed. São Paulo: Alfa-Ômega, 1978. p.137.

BENEVIDES. Maria Victória de Mesquita. A UDN e o Udenismo: ambiguidades do liberalismo brasileiro (1945-1965). Rio de Janeiro: Paz e Terra, 1981.

FERREIRA, Jorge; DELGADO, Lucilia de Almeida Neves. O tempo do nacional-estatismo: do início da década de 1930 ao apogeu do Estado Novo. $6^{\mathrm{a}}$ ed. Rio de Janeiro: Civilização Brasileira, 2013.

FRANCO, Afonso Arinos de Melo. História e Teoria dos Partidos Políticos no Brasil. 2 ed. São Paulo: Alfa Omega, 1974.

GAMA NETO. Ricardo Borges. "A legislação eleitoral de 1945 e suas consequências políticas". In: Textos \& Debates. vol. 1. n 1. 1995.

GOMES, Ângela Maria de Castro. A invenção do trabalhismo. 3 ed. Rio de Janeiro. Editora $F G V, 2005$.

MAGALHÃES, Juracy. Minhas memórias provisórias. Depoimento prestado ao CPDOC / Coord. Alzira Alves de Abreu. Rio de Janeiro: Civilização Brasileira, 1982.

PANG, Eul-Soo. Coronelismo e Oligarquias (1889-1934): a Bahia na Primeira república Brasileira. Trad. Vera Teixeira Soares. Rio de Janeiro: Civilização Brasileira, 1979.

SOUZA, Maria do Campello de. Estado e Partido Políticos no Brasil (1930-1964). São Paulo: Alfa Ômega, 1983.

SENA JUNIOR, Carlos Zacarias F. de. Os impasses da estratégia: os comunistas, o antifascismo e a revolução burguesa no Brasil (1936-1948). São Paulo: Annablume, 2009.

SILVA, Paulo Santos. A volta do jogo democrático (Bahia, 1945). Salvador: Assembleia Legislativa. 1992. 
Âncoras de tradição: luta política, intelectuais e construção do discurso histórico na Bahia (1930/1949). Salvador: EDUFBA, 2011.

SILVA, Paulo Santos; SENA JUNIOR, Carlos Zacarias F. de. O Estado Novo: as múltiplas faces de uma experiência autoritária. Salvador: EDUNEB, 2008.

WEFFORT, Francisco. O populismo na política brasileira. $3^{\mathrm{a}}$ ed. Rio de Janeiro: Paz e Terra. 1980.

ARTIGO ENVIADO EM: 15/05/2017

ARTIGO ACEITO PARA PUBLICAÇÃO EM: 20/12/2017 